Magdalena Ickiewicz-Sawicka

Katedra Ekonomii i Nauk Społecznych

Politechnika Białostocka

http://dx.doi.org/10.18778/8088-249-2.20

\title{
BOŚNIACCY MUZUŁMANIE (BOSZNIACY) W OBLICZU KRYMINOGENNEGO I RADYKALNEGO ISLAMU NA BAEKANACH - PRZYPADEK BOŚNI I HERCEGOWINY
}

\section{Muzulmanie (Boszniacy) - problem z identyfikacją tożsamości}

Boszniacy mają etniczny słowiański rodowód wspólny z Serbami, Chorwatami i Macedończykami, różnią się natomiast od tych nacji religią. Konwersji na islam dokonywali w czasie przymusowego funkcjonowania w Osmańskim Imperium. Motywy zmiany religii nie zostały jednoznacznie określone, choć znaczącym powodem były społeczno-ekonomiczne przywileje dla ludności wyznającej islam (zwolnienie z płacenia podatku od „niewiernych” - dżizja - i możliwość nabywania ziemi). Równie ważnym argumentem za przyjęciem islamu okazały się także pobudki religijne oraz kulturowo-polityczne.

Bliska Boszniakom jest przesiąknięta orientem słowiańska kultura ludowa. W rezultacie przenikania się różnych tradycji w tej części Europy, Boszniacy stworzyli swoisty kulturowy melanż z doskonale zachowanymi archaicznymi formami kultury materialnej i duchowej, zwłaszcza literatury ustnej (ludowymi pieśniami epickimi i lirycznymi, bogatą prozą). Boszniacka tożsamość [Skowronek i in. 2005; Szwat-Gylybowa: 2005] narodowa [Smith 1993; Huntington 2004] przez wieki była zależna od zewnętrznych, autorytarnych systemów politycznych. Obejmowała siedem zasadniczych różnych cywilizacyjnych, politycznych i prawnych paradygmatów: w Banowinie / Królestwie Bośni (od IX w. do 1463 r.); Imperium Osmańskim (1463-1878); Austro-Węgrach (1878-1918); I Jugosławii (1918-1941); Niepodległym Państwie Chorwackim (1941-1945); II Jugosławii (1945-1992); a od roku 1992 w państwie Bośnia i Hercegowina. Jej polityczny los wyznaczyły zaś trzy traktaty pokojowe: z Berlina (1878), Wersalu (1919) i Dayton / Paryża (1995) [Lovrenović 2012]. W związku z tym, żadna ze wskazanych wyżej tradycji polityczno-społecznych nie została zaakceptowana przez większość mieszkańców współczesnej Bośni i Hercegowiny ani na poziomie emocji, ani pamięci. 
Historia tego państwa nie zależała od dynamiki przemian ustrojowych przechodzenia od jednej formy państwowości do drugiej, ale raczej od wpływu zewnętrznych sił, które doprowadziły do jego głębokiej dezintegracji społecznej, politycznej i gospodarczej.

Po okresie niepodległości w średniowieczu, w epoce osmańskiej ostatecznie została zaprzepaszczona możliwość stworzenia wspólnej tożsamości politycznej [Postmes, Branscombe 2010] trzech grup etnicznych, które różnią się między sobą przede wszystkim religią - dzisiejszych Serbów, Chorwatów i Boszniaków. Trzeba dodać, że były one i wciąż są emocjonalnie związane, odpowiednio: z Belgradem, Zagrzebiem i Stambułem. Pozostałością po ponad czterystu latach osmańskiego panowania jest tzw. kompleks turecki - w przypadku Boszniaków wyrażający poczuciem „niższości”, a w przypadku Serbów i Chorwatów - „wyższości" względem pozostałych bałkańskich nacji. Kompleks stał się podstawą trzech przeciwstawnych wizji tożsamości przejawiających się w hasłach: ,jesteśmy Turkami” (Boszniacy - nierozerwalnie związani z Imperium Osmańskim), „jesteśmy przedmurzem chrześcijaństwa” (Chorwaci - wierni tradycji monarchii austro-węgierskiej), „wracamy do wiary przodków” (Serbowie - utożsamiający się z I i II Jugosławią) [Lovrenović 2012]. Taki podział tożsamości rodził z kolei dychotomie: swój-obcy, przyjaciel-wróg, Wschód-Zachód, łacina-greka. W związku z tym zawsze te tożsamości pozostawały w konflikcie i wewnętrznym rozdarciu. $\mathrm{Z}$ tego też powodu na Bałkanach na tym terenie prowadzono walki o tożsamość; z całą pewnością też konflikt tożsamości stał się przyczyną tego, że ludzie z dnia na dzień stawali się seryjnymi zabójcami. W ciągu wielu lat trwania etniczych nieporozumień powstały zranione społeczności pielęgnujące swoje dalekie od racjonalności mity i rytuały, marzenia i oczekiwania, uwikłane w kult niedokończonej przeszłości, która ujawnia się w krwawej konfrontacji wojny domowej [Maalouf 2002]. Wydarzenia te przyczyniły się do pozbawienia ludzi memoria passionis, czyli obowiązku pamiętania o cierpieniu niewinnych ludzi, co uczyniło życie zaledwie typem antropomorfizmu, a człowieka - inteligentnym robotem bez pamięci i moralności [Livingston i in. 2006: 275-283]. Dlatego też społeczeństwo Bośni i Hercegowiny żyje chęcią zemsty, kierując się zasadą: „musimy ich pokonać, zanim oni pokonają nas” [Lovrenović 2012]. W tej konfiguracji ważną funkcję wśród boszniackiego społeczeństwa nadal pełni przynależność religijna. To właśnie religia odegrała kluczową rolę w kształtowaniu tożsamości Boszniaków, zaś postrzeganie, co jest prawomocne, a co takie nie jest, zakorzenione jest raczej w nauczaniu religijnym niż w prawie cywilnym. Owa religijna tożsamość wpływa na nieustanną mitologizację przestrzeni politycznej, w której powojenny paradygmat kulturowy wciąż się utrzymuje. Najdotkliwszą konsekwencją takiego stanu rzeczy jest pojawienie się silnych emocji związanych z kultem cierpienia, zgodnie, z którym winowajcę własnej niepewnej sytuacji rozpoznaje się w najbliższym sąsiedzie. Pojęcia: 'wróg' i 'inny' stają się tym samym synonimiczne, co okazuje się charakterystyczną cechą wspólną wszystkim połu- 
dniowosłowiańskim nacjonalizmom [Lovrenović 2012]. Mit wroga przekształca się w polityczny mit konspirującej społeczności, w zderzeniu, z którą jedynym rozsądnym rozwiązaniem jest bezkompromisowa walka.

Nie ulega wątpliwości fakt, że spoiwem boszniackiego narodu od zawsze była religia - niezmienny element narodowej tożsamości i identyfikacji w bałkańskim tyglu kulturowym. Do końca XX w. boszniacka wersja islamu była liberalna, wyjątkowo tolerancyjna, raczej folklorystyczna. Ten pozytywny obraz runął wraz $\mathrm{z}$ ostatnią wojną domową i pojawieniem się na terytorium Bośni przedstawicieli fundamentalistycznego islamu w postaci wahhabitów i mudżahedinów. Obecnie to ta wersja religii muzułmańskiej coraz częściej staje się bardziej atraktycja dla wielu Boszników pozbawionych perspektyw życiowych i szansy na lepszą przyszłość.

\section{Idee fundamentalistycznego islamu na Bałkanach}

Rozpad Jugosławii doprowadził do tego, że pozostałe bośniackie nacje takie jak Chorwaci i Serbowie poczuli się mniejszościami narodowymi w swoim własnym kraju. Dominujący bośniaccy muzułmanie na nowo zdefiniowali swą tożsamość etniczno-narodową i zaczęli określać się, jako Bośniacy czy też Bośnianie (obecnie Boszniacy), a swymi manifestacjami rozpoczeli walkę o niezależność etniczną i państwową. Niemniej jednak w wyniku tego rodzaju działań bośniaccy muzułmanie, niemal zamknęli się we własnym gettcie. Mieszane małżeństwa spotykały się z olbrzymią krytyką, zaczęto pielęgnować zwyczaje muzułmańskie, a na znaczeniu zyskały przepisy dotyczące ubioru kobiet. W chwili, gdy islam stał się celem ataków etnicznego nacjonalizmu, powrócono do fundamentów religijnych i nadano im radykalną postać. W 1992 r., kiedy to ONZ wprowadziło embargo na dostawy broni do Bośni, zbrojny opór muzułmanów został znacznie osłabiony. Dopiero 4 lata później, gdy liczba ofiar sięgnęła blisko 100 tysięcy, Stany Zjednoczone zdecydowały się na podjęcie interwencji zbrojnej w byłej Jugosławii [Elsaesser 2007: 296].

W związku z tym muzułmanie na Bałkanach, uzyskując tak mocne wsparcie ze strony NATO, a następnie Unii Europejskiej, poczuli się wyjątkowo mocni, tym bardziej, że byli także „dyskretnie” wspierani przez Arabię Saudyjską czy Zjednoczone Emiraty Arabskie. Należy wyraźnie zaznaczyć, że pomoc ta była przeznaczona wyłącznie dla fundamentalistów islamskich, prezentujących ortodoksyjną odmianę islamu. Przejawiała się ona w lokalnej agresji i natarczywości samozwańczych policji religijnych np. kazano nosić kobietom nikab, zezwalano na półoficjalne wielożeństwo, budowano meczety czy szkoły koraniczne propagujące ideologię wahhabicką [Hamid: 2002: 42]. Począwszy od Afganistanu i klęski operacji wojennej ZSRR w świecie islamskim rozpoczął się etap walki partyzanckiej, w której nierzadko wykorzystywano techniki terrorystyczne bę- 
dące konsekwencją fundamentalizmu religijnego propagowanego przez mułłów pochodzących z terenów pusztuńskiego pogranicza pakistańskiego-afgańskiego. Szacuje się, że operacja afgańska zaangażowała do walki przeciwko „niewiernym” około 150000 mudżahedinów pochodzących z całego świata islamu [Gerges 2007: 101]. Oblicza się także, że kilka tysięcy tych bojowników przybyło na Bałkany i walczyło w Bośni, a potem w Kosowie i Macedonii.

„Dyskretna pomoc” Zachodu podczas konfliktu w Afganistanie (w imię walki z komunizmem) - przyniosła nieoczekiwane konsekwencje w postaci pojawienia się w trakcie wojny na Bałkanach oddziałów mudżahedinów [Kohlmann 2004] na terytorium dzisiejszej Bośni i Hercegowiny. Służby specjalne państw zachodnich czynnie współdziałały z dżihadystami, którzy masowo przybywali do Bośni. To tu, w trakcie walk, rozpoczęto okrutne egekucje łącznie $\mathrm{z}$ obciniem głów czy gotowaniem w kotłach członków innych grup religijnych (o tych licznych faktach nie wspominało się wówczas w mediach), co z kolei spowodowało kontrreakcję osamotnionych - formalnie i medialnie - Serbów zamieszkałych w Bośni i w nowej Jugosławii [Kohlmann 2004]. Jednocześnie zaś nie wszyscy bośniaccy muzułmanie godzili się na taki rozwój sytuacji, fundamentalistyczne podejście do religii, ksenofobię oraz konserwatyzm pochodzący z krajów arabskich. Przykładem tego rodzaju działań są m.in. dzieje Fikreta Abdićia ${ }^{1}$. Generalnie zaś islam bośniacki był niesłychanie zlaicyzowaną i zeuropeizowaną formą religii muzułmańskiej. W socjalistycznej Jugosławii pełnił formalną funkcję muzułmańskiego folkloru Sarajewa, Tuzli czy Zenicy, będąc jednocześnie przykładem ewolucji, jakiej podlega w warunkach wielokulturowej Europy także religia.

Grupa wojowników, którzy zaczęli przybywać do Bośni przez Chorwację w 1992 r., składała się zarówno z Arabów z Egiptu, Arabii Saudyjskiej, Algierii, Jemenu, jak i muzułmanów z Afryki i Azji. Początkowo nie dołączyli oni do armii bośniackiej, ale działali niezależnie, posługując się innymi metodami niż bośniacka armia. Instalowali pola minowe, porywali serbskich żołnierzy, a następnie mordowali ich w okrutny sposób, jednocześnie filmując egzekucję. Prowadzili działalność przestępczą, uczestniczyli w walkach a także organizowali przedsięwzięcia logistycznyne, takie jak dostarczanie broni i bojowników. Jednak w 1993 r., po serii incydentów i doniesień o zbrodniach wojennych przeciwko ludności serbskiej i chorwackiej, zostali wcieleni do armii bośniackiej jako specjalnie utworzona w tym celu odrębna jednostka - oddział Al-Mudżahid.

Materiały rozpowszechniane przez wojowników ukazywały, że koordynują oni swoje działania z pomocą niewielkiej liczby wysokich rangą dowódców bośniackich, którzy wiedzieli, że mają do czynienia z ludźmi poszukiwanymi między-

${ }^{1}$ Patrz szerzej: http://www.aimpress.ch/dyn/trae/archive/data/200108/10807001-trae-sar.htm (20.02.2016). 
radorowymi listami gończymi. Jeden z dowódców oddziału Al-Muhadżid, Algierczyk o nazwisku Abu Al-Maali (alias Abd Al-Qader Mukhtari, członek algierskiej organizacji dżihadystycznej GIA, identyfikowany przez Amerykanów jako „mały Osama bin Laden”) [Jacquard: 2002: 66-70], podkreślił, że otrzymywał rozkazy bezpośrednio od przywódcy Bośni Aliji Izetbegovića i szefa sztabu Bośni, Rasima Delića, ten ostatni był sądzony za zbrodnie wojenne w 2008 r. i skazany na trzy lata pozbawienia wolności ${ }^{2}$. Generalnie zaś, ideologicznym i politycznym przywódcą mudżahedinów był szejk Anwar Shaban, założyciel Islamskiego Ośrodka Kultury w Mediolanie i członek egipskiej Al-Gamaa Al-Islamiyya oraz weteran wojny w Afganistanie. W 1991 r. uzyskał azyl polityczny we Włoszech i wraz z wybuchem wojny w Bośni stał się kluczową postacią w logistycznym aparacie rekrutowania, finansowania i transportowania mudżahedinów do Bośni oraz dostaw broni. Został zabity w 1995 r. na chorwackim punkcie kontrolnym w Bośni wraz z trzema wysokimi rangą dowódcami oddziału Al-Mudżahid [Jacquard: 2002: 66-70].

Ponadto, należy wyraźnie zaznaczyć, że wielu islamskich bojowników, którzy przybyli do Bośni, działało w poczuciu misji religijno-ideologicznej. Byli oni przekonani, że wojna domowa jest wynikiem ucisku i dyskryminacji bośniackich muzułmanów, którzy porzucili „prawdziwą wiarę” i dlatego muszą ponieść ofiarę krwi oraz powrócić do islamskich tradycji i korzeni, tj. salafizmu - muzułmańskiego ruchu religijnego i politycznego, postulującego odrodzenie islamu poprzez powrót do jego pierwotnych źródeł, „religii przodków”. Za pioniera salafizmu uważa się Ibn Tajmijję, który potępił współczesne mu filozoficzne i sufickie interpretacje islamu, postulując powrót do jego pierwotnej formy, oczyszczonej z późniejszych naleciałości. Termin salafiyya odnosi się jednak przede wszystkim do nurtów reformatorskich wewnątrz islamu powstałych w wieku XIX, które nawiązywały do myśli Ibn Tajmijji. Wcześniej jednak, bo w wieku XVIII, narodził się postulujący powrót do pierwotnego islamu wahhabizm. Z salafizmu wywodzi się XX-wieczny fundamentalizm islamski [Danecki 1998]. Salafici wyróżniają się ubiorem. Mężczyźni noszą szerokie spodnie o skróconych i zwężonych nogawkach, galabije (rodzaj tuniki) i tadije (płytkie obcisłe czapeczki, najczęściej białego koloru). Zimą na ten ubiór wkładają kurtki. Kobiety zaś ubierają się w hidżaby (chusty) i abaje (długie, sięgające kostek płaszcze) [Izak 2013: 53].

Chociaż liberalnym bośniackim muzułmanom tego rodzaju zwyczaje i strój był obcy, dla salafitów arabskich stanowiło zasadniczy element ich globalnego posłannictwa. Bośniacki kryzys był kolejnym sposobem mobilizowania muzułmanów na całym świecie, by dołączyli do światowej walki o zwycięstwo islamu, tak jak w Afganistanie, później w Iraku, a obecnie w ISIS [Cockburn 2015].

${ }^{2}$ Patrz szerzej: http://www.un.org/apps/news/story.asp?NewsID=28057\&Cr= ICTY\&Cr1=\#.VVsxos5jCv4 (20.02.2016). 
Tuż po zakończeniu wojny w Bośni i Hercegowinie, „zatrute ziarno” fundamentalistycznego islamu zaczęło przynosić równie zatrute owoce. Wówczas zyskała na znaczeniu postać jednego z najbardziej wplywowych wahhabickich ideologów - ostatniego przywódcy religijnego El-Mudżahid - Imad al-Misri (Masri), członka ścisłego kierownictwa Dżama’a al-Islamijja fi Misr (Egipskiej Grupy Islamskiej) [Balcer 2003: 217-218]. Po wojnie wielu arabskich ochotników pozostało w Bośni i Hercegowinie i założyło rodziny z Bośniaczkami. Przyłączyło się do nich wielu miejscowych radykałów, którzy wraz z nimi brali udział $\mathrm{w}$ walkach. Ideę wahhabizmu propagowali również pracownicy charytatywnych organizacji pomocowych, oficjalnie zarejestrowanych w Bośni i Hercegowienie. Jedym z przykładów była organizacja Al-Haramajn działająca w większości krajów muzułmańskich oraz w Europie i Stanach Zjednoczonych. W 2003 r. Departament Stanu USA uznał ją za organizację wspierającą terroryzm i związaną z Osamą bin Ladenem [Elsässer: 2007: 179-183; Kepel 2003: 241-258; Marchand 2004: 62-66; Parzymies 2003: 233; Parzymies 2005: 159-163].

Kolejnym przykładem takiej organizacja była grupa Mirsada Bektaszevicia, która w styczniu 2007 r. została rozbita, a jej przywódca został skazany prawomocnym wyrokiem sądu w Sarejewie na 15 lat pozbawienia wolności. Kolejni członkowie grupy uzyskali następujące wyroki: Turka Abdulkarima Cesura skazano na karę 13 lat pozbawienia wolności, Bajro Ikanovicia na 8 lat, a Senada Hasanovicia na 2,5 r. więzienia [Skieterska 2008; Berić 2011]3․ Następnie w październiku 2005 r. zlikwidowano niewielką komórkę miejscowych (działających na terenie Bośni i Hercegowiny) terrorystów, którzy dysponowali bronią i materiałami wybuchowymi, a także planowali przeprowadzenie zamachu na bazę Sił Unii Europejskiej (EUFOR) w Sarajewie. Ich przywódcą był Mirsad Bektaszević alias Maximus - Bośniak ze szwedzkim obywatelstwem, który rekrutował zwolenników w Danii oraz Wielkiej Brytanii oraz utrzymywał łączność z komórką terrorystyczną w Kanadzie. Według FBI jeden z londyńskich kontaktów Bektaszevicia współpracował z ekstremistami w Atlancie. Wszyscy członkowie komórki zostali aresztowani. W marcu 2008 r. zatrzymano kolejnych pięciu podejrzanych, jednak ci wkrótce zostali zwolnieni. Ustalono, że utrzymywali oni kontakty z radykalnym imamem Muhammadem Porczą z Wiednia [Chodakiewicz 2009].

Obecnie liczbę wahhabitów w tym kraju ocenia się na 3 tys., a rzeszę ich sympatyków na około 50 tys. (tj. 3 proc. ludności muzułmańskiej). Bośniaccy wahhabici prowadzą działalność sprzeczną z interesami Wspólnoty Muzułmańskiej (Islamskiej Zajednica - IZ), czyli tradycyjnego bałkańskiego i tolerancyjnego islamu. Wahhabici negują tradycyjne pojmowanie i praktykowanie islamu przez bośniackich muzułmanów. Otwarcie krytykują bośniacki islam za laicyzację (ilhad), odejście od źródeł i zaśmiecenie ich grzesznymi innowacjami (bida) lub

\footnotetext{
${ }^{3}$ Mustafa Cerić, zob. http://de.wiki (20.02.2016).
} 
wręcz herezję (zandaka) i apostazję (ridda) [Izak 2013: 52-74]. Konflikty pomiędzy wahhabitami a innymi muzulmanami oraz próby zajęcia meczetów przez islamskich radykałów nasiliły się od końca 2006 r. w całej Bośni i Hercegowiny, Sandżaku i Czarnogórze ${ }^{4}$. W miejscowości Gornja Maocza, w której po wojnie domowej osiedliło się wielu arabskich mudżahedinów, budując zamkniętą społeczność, radykałowie utworzyli nielegalną szkołę podstawową z jordańskim systemem nauczania (pomimo stwierdzenia nieprawidłowości władze bośniackie nie podjęły stosownych działań). Ponadto wspólnoty wahhabickie koncentrują się również w kilku innych rejonach w środkowej Bośni, jak: Tuzla, Travnik, Zenica, Maocza, Boczinja, Sutjeska i Osmacza; w Kantonie nr 1 (Sanski Most i Cazin Bihać, Bosanska Krupa), w Sarajewie i jego okolicach (Dobrinja, Ilidża, Buca Potok, Hadżici, Visoko), w kilku miastach nad Neretwą (Konjic, Jablanica, Mostar) oraz w rejonie Brczko [Chodakiewicz 2009]. Generalnie tego rodzaju organizacje charytatywne stanowią znakominy punkt zaczepienia a następnie zakorzeniena organizacji terrorystycznych, które pod pozorem praktykowania religii szerzą radykalny islam i dopuszczają się aktów przemocy. Charyzmatycznym przywódcą bośniackich wahhabitów, ich ideologiem i kaznodzieją, był zmarly w marcu $2007 \mathrm{r}$. Jusuf Barczić (Death of Bosnian Veha- bities Leader [online], „WAVE. International Youth Web Magazine" 2007, nr 6, http://www.wavemagazine. net. Obecnie zaś przywódcami wahhabitów są Husin Imad alias Abu Hamza (Syryjczyk z bośniackim obywatelstwem) i Karraj Kemal bin Ali alias Abu Hamza (naturalizowany Tunezyjczyk), który za udział w wojnie 1992-1995 został odznaczony Orderem Złotej Lilii [Izak 2013: 52-74]. Obaj przywódcy domagają się wprowadzenia szariatu, twierdząc, że „na ziemi Allaha powinno panować prawo Allaha”. Karraj Kemal jako bohater wojenny cieszy się dużym poważaniem również w szerokich kręgach młodzieży muzułmańskiej, byłych mudżahedinów i weteranów Armii Republiki Bośni i Hercegowiny. Bośniackich wahhabitów (Nusreta Imamovicia, przewodniczącego wahhabickiej wspólnoty w Gornjej Maoczy i Bilalema Bosniciema - stojącego na czele radykałów w Bihaciu) wspierają muzułmańskie wspólnoty działające w Austrii (Wiedeń) kierowane przez Muhammada Porczę oraz Nedżada Balkana. Wśród bośniackich wahhabitów aktywnie działa także ruch Poziv u Raj (Wezwanie do Raju), którego celem jest m.in. wychowanie dzieci w duchu radykalnego islam [Ceresnjes, Green: 2016]. W Gornjej Maoczy Imamović wprowadził szariat i zaangażował się w działalność propagandową prowadzoną przez Internet. Na początku 2012 r. na krótko został aresztowany pod zarzutami szerzenia nienawiści religijnej, nielegalnego posiadania broni, głoszenia propagandy wymierzonej przeciwko konstytucyjnym organom państwa i nawoływania do przemocy. Był również podejrzewany o współudział w zamachu na ambasadę Stanów Zjednoczonych w Sarajewie [Izak 2013: 52-74].

${ }^{4}$ [Maye: 2009: 30-33] oraz http://religiapokoju.blox.pl (20.02.2016). 
Z bośniackimi wahhabitami sympatyzuje także Aktivna Islamska Omladina AIO (Aktywna Młodzież Muzułmańska). Idea utworzenia tej organizacji zrodziła się wiosną 1995 r. wśród młodych bośniackich bojowników jednostki, którą tworzyli głównie ochotnicy z krajów arabskich, walczący m.in. w El-Mudżahid. Służył w niej Nezim Haradżić uważany za twórcę AIO. Haradżić w latach 90. XX w. regularnie podróżował do Arabii Saudyjskiej. W wydanym w 1995 r. manifeście AIO napisano m.in.: „Celem jest założenie islamskiego państwa w Bośni i Hercegowinie, które będzie oparte wyłącznie na zasadach szariatu, a najlepszym jego wzorem jest Arabia Saudyjska. Aby można było osiągnąć ten cel, trzeba zmienić system szkolny w BiH”’ . Aktywna Młodzież Muzułmańska jest największą organizacją islamską w tym kraju. W sierpniu 1997 r. Ismet Fazlić zastąpił Nezima Haradżicia na stanowisku przewodniczącego. Po nim funkcję tę przejął Adnan Pezo, który służył w tej samej jednostce El-Mudżahid co Haradżić i w drugiej połowie lat 90. był również przywódcą organizacji Vehabija związanej z AIO' . Między rokiem 1997 a końcem 1998 powstało wiele nowych rad AIO - ich liczba wzrosła do 26. Znacznie zwiększyła się też liczba członków i aktywistów, co wymusiło przeprowadzenie zmian organizacyjnych. W październiku 2000 r. siedziba naczelnych władz organizacji została przeniesiona z Zenicy do Sarajewa.

Działacze Vehabiji skłaniają się ku purytańskiej i dogmatycznej interpretacji islamu, charakterystycznej dla Arabii Saudyjskiej. W 2002 r. organizacja liczyła podobno 2-3 tys. członków. Obecnie ocenia się, że jest ich około 3 tys. Liczbę sympatyków szacuje się w przybliżeniu na 50 tys., czyli około 3 proc. ludności Bośni i Hercegowiny. Uważa się, że członkowie Vehabiji stali za próbami zamachów bombowych przeprowadzonych w Sarajewie - w 2001 r. na ambasadę Stanów Zjednoczonych i w 2006 r. na bazę sił EUFOR 7.

W 1997 r. z organizacji odeszła grupa działaczy, która utworzyła Stowarzyszenie Obywateli Al-Furkan. Na jego czele stanął Nermin Karadżić. W czerwcu tego roku z inicjatywy saudyjskiego Światowego Zgromadzenia Młodzieży Muzułmańskiej (World Assembly of Muslim Youth - WAMY) ${ }^{8}$ młodzieżowe organizacje w Bośni utworzyły Radę Koordynacyjną. W kwietniu 2001 r. jeden z działaczy AIO, Faruk Viszcia, założył organizację Islam Bosnia (Islamska Bośnia), będącą filią Braci Muzułmanów (Al -Ichwan al-Muslimin). W 2002 r. członkowie organizacji: AIO, Al-Furkan i Islam Bosnia protestowali wspólnie przed sarajewskim więzieniem, aby nie dopuścić do ekstradycji pięciu obywateli Algierii i jed-

5 Organizacja Aktivne Islamske Omladine, borci za eksteritorijalni talibanski district u Zenici i Alipasinom Polju, Arhiva Dani 72, marzec 1998.

${ }^{6}$ Bałkany moga stać się wylęgarnia terrorystów, [online], http://www.euroislam.pl (20.02. 2016).

7 Tamże.

${ }^{8}$ Patrz szerzej: http://www.wamy.org (15.02.2016). 
nego Jemeńczyka podejrzanych o próbę zorganizowania zamachu na Ambasadę Stanów Zjednoczonych w Sarajewie w 2001 r. [Izak: 2013: 52-74]. Członkowie AIO biorą udział w pracach komitetów miejskich, a także prowadzą działalność za pośrednictwem sześciu Młodzieżowych Centrów Kulturalnych (Omladinski kulturni centri - OKC) znajdujących się w Tuzli, Zenicy, Zavidovici, Travniku, Sanskim Moste i Gornji Vakuf). Ponadto za jednego z ważnych działaczy AIO i duchowego przywódcę bośniackich wahhabitów uznaje się Nezima Halilovicia alias Muderis, imama meczetu króla Fahda w Sarajewie. AIO utrzymuje kontakty z Muzułmańską Organizacją Humanitarną - Miłosierdzie Merhamet ${ }^{9}$ ), wspieraną przez Saudyjską organizację charytatywną, której od 2002 r. zakazano działalności w Bośni i Hercegowinie. Bośniacki Merhamet został założony w 1913 r. w celu wspierania ubogiej ludności muzułmańskiej. W 1946 r. organizacja ta została reaktywowana, ale działalność swą rozpoczęła dopiero od początku lat 90. XX w. Nieoficjalnym celem Merhamet jest m.in. szerzenie irańskich wpływów wśród muzułmańskich wspólnot na Bałkanach. Merhamet bez przeszkód finansuje AIO. Także w serbskiej prowincji Sandżak [Zalewski 2010] dochodziło do incydentów z udziałem wahhabitów, którzy siłą próbowali przejąć główny meczet w stolicy regionu (Novi Pazar). Zagadnienia te jednak wychodzą poza ramy niniejszego opracowania i wymagają oddzielnej analizy. Podobnie przedstawia się sytuacja Boszniackich wojowników walczących w szeregach Daesh. W związku z tym odsyłam do literatury kompleksowo opisującej tego rodzaju związki.

\section{Podsumowanie}

Jak wskazują powyższe rozważania, bezwarunkowe poparcie Zachodu udzielone najbardziej skrajnym elementom bośniackiego fundamentalistycznego islamu w przeszłości i jednoznaczne opowiedzenie się za muzułmańskim państwem na Bałkanach spowodowały zakorzenienie się skrajnych postaw w tej części Europy. Ten kraj jest obecnie obszarem realnie zagrożonym ekspansją wojującego islamu w postaci szerzenia się ideologii wahhabitów na terytorium Bałkanów Zachodnich. Pośredno jest to wynikiem skomplikowanej i niejednorodnej tożsamości bośniackich muzułmanów (Boszniaków), którzy nadal poszukują swojego miejsca w bałkańskim tyglu: narodów, grup etnicznych, wspólnot religijnych czy systemów politycznych lub gospodarczych. Najtrafniej tę boszniacką tożsamość ujął pisarz Ivo Andrić, twierdząc, że mieszkaniec Bośni i Hercegowiny od wieków doświadcza losu człowieka lewantyńskiego, „prochu ludzkiego, co mozolnie prześlizguje się między Wschodem a Zachodem, nie należąc do żadnego z nich, a dostając cięgi od obu”. Człowiek Bośni i Hercegowiny był i pozostaje nadal ofiarą wielkiej historii i polityki.

\footnotetext{
9 Merhamet, http://www.merhamet.co.ba (23.02.2016).
} 


\section{LITERATURA}

[Aresztowano... 2008] - Aresztowano pięciu domniemanych terrorystów, „Biuletyn Prasowy ABW", 25.03.2008, dział: Terroryzm.

[Balcer 2003] - A. Balcer, Polityczny islam w Bośni oraz jego związi z Bliskim Wschodem i muzutmańskim terroryzmem, [w: ] Islam a terroryzm, red. A. Parzymies, Wydawnictwo Akademickie Dialog, Warszawa, s. 217-218.

[Chodakiewicz 2009] - M. J. Chodakiewicz, Islam na Bałkanach, „Tygodnik Solidarność”, 15.09.2009.

[Cockburn 2015] - P. Cockburn, Państwo Islamskie, PWN, Warszawa.

[Danecki 1997] - J. Danecki Podstawowe wiadomości o islamie, t. 1-2, Wydawnictwo Akademickie Dialog, Warszawa.

[Elsaesser 2007] - J. Elsaesser, Jak dżhad przybyt do Europy (wojownicy Boga i tajne stuzby na Batkanach), Wydawnictwo MUZA SA, Warszawa.

[Gerges 2007] - A. Gerges, Journey of the Jihadist: Inside Muslim Militancy, Harcourt Press, New York.

[Hamid 2002] - A. Hamid, Wahhabism: A Critical Essay, Islamic Publications International.

[Izak 2013] - K. Izak, Radykalny islam na Bałkanach źródtem konfliktów społecznych $i$ terrorystycznego zagrożenia dla Europy, „Przegląd Bezpieczeństwa Wewnętrznego”, t. 13 , nr 9.

[Kepel 2003] - G. Kepel, Święta wojna. Ekspansja i upadek fundamentalizmu muzutmańskiego, Wydawnictwo Akademickie Dialog, Warszawa.

[Kohlmann 2004] - Evan F. Kohlmann, Al-Qaida's Jihad in Europe: The Afghan-Bosnian Network Paperback use preformatted date that complies with legal requirement from media matrix - November 25.

[Livingston i in. 2006] - J. C. Livingston, F. Schüssler Fiorenza, Modern Christian thought: the twentieth century (Second ed.), Fortress Press, Minneapolis, s. 275-283.

[Maalouf 2002] - A. Maalouf, Zabójcze tożsamości, Państwowy Instytut Wydawniczy. Warszawa.

[Marchand 2004] - S. Marchand, Arabia Saudyjska. Zagrożenie, Wydawnictwo Akademickie Dialog, Warszawa.

Organizacja Aktivne Islamske Omladine, borci za eksteritorijalni talibanski district u Zenici i Alipasinom Polju, Arhiva Dani 72, marzec 1998.

[Parzymies 2003] - A. Parzymies (red.), Islam a terroryzm, Wydawnictwo Akademickie Dialog, Warszawa.

[Parzymies 2005] - A. Parzymies, Muzutmanie w Europie, Wydawnictwo Akademickie Dialog, Warszawa.

[Postmes, Branscombe 2010] - T. Postmes, N. Branscombe, Sources of social identity, [w: ] T. Postmes, N. Branscombe (eds), Rediscovering Social Identity: Core Sources. Psychology Press, New York.

[Roland 2002] - J. Roland, In the Name of Osama Bin Laden, Duke University Press, Durham, UK.

[Skowronek i in. 2005] - J. Skowronek, M. Tanty, T. Wasilewski, Stowianie potudniowi i zachodni VI-XX wiek, Wydawnictwo Naukowe PWN, Warszawa. 
[Smith 1993] - A. D. Smith, National identity (Ethnonationalism in Comparative Perspective), University of Nevada Press, Nevada.

[Szwat-Gyłybowa 2005] - G. Szwat-Gyłybowa, Bogomilstwo. Powieść elementarna, [w: ] Haeresis bulgarica $w$ bułgarskiej świadomości kulturowej, Warszawa.

[Zalewski 2010] - K. Zalewski, Naród, religia, rasa: muzutmańskie ideologie i ruchy narodowe pogranicza $w$ Południowo-Wschodnej europie: przykład Sandżaku nowopazarskiego w XX wieku, Warszawa.

\section{Źródla internetowe}

Batkany moga stać się wylęgarnią terrorystów [online], http://www.euroislam.pl (20.02.2016).

[Berić 2016] - G. Berić, Czy Bośni grozi konflikt religijny [online], http://forum.gazeta. pl (20.02.2016).

[Ceresnjes, Green 2012] - A. Ceresnjes, R. Green, The Global Jihad Movement in Bosnia - A Time Bomb in the Heart of Europe [online], „MEMRI”, 22.06.2012, http:/ / www. memri.org (20.02.2016).

Death of Bosnian Veha- bities Leader [online], „WAVE. International Youth Web Magazine” 2007, nr 6,http://www.wavemagazine. net (20.02.2016).

http://konflikty.wp.pl/kat,122594,title,Obcinanie-glow-cwiartowanie-cial-mroczny-konflikt, wid,13975996,wiadomosc.html (20.02.2016).

http://sjp.pwn.pl/sjp/;2568551 (20.02.2016).

http://www.aimpress.ch/dyn/trae/archive/data/200108/10807-001-trae-sar.htm (20.02.2016).

http://www.merhamet.co.ba (20.02.2016).

http://www.un.org/apps/news/story.asp?NewsID=28057\&Cr=ICTY\&Cr1=\#.VVsxo-

s5jCv4 (20.02.2015).

http://www.wamy.org (20.02.2016).

[Huntington 2004] - Samuel P. Huntington, Who Are We: Test" Huffington Post, http://www.huffingtonpost.com/jaketownsend/branding-peace-norways-id_b_918229.h.

[Lovrenović 2012] - D. Lovrenović, Trzy religie, historie, narody - jedno państwo, 2012, nr 688, http://www.miesiecznik.znak.com.pl/6882012dubravko-lovrenovicbosniai-hercegowi-na-zly-pokoj-trzy-religie-historie-narody-jedno-panstwo / (20.02.2016).

[Mayer 2009] - W. Mayer, Piata kolumna Proroka, „Forum”, nr 11, s. 30-33, [w: ] Radykałowie islamscy w Bośni [online], http:// religiapokoju.blox.pl (20.02 2016).

[Skieterska 2008] - A. Skieterska, Nie każdy wahhabita jest terrorysta, „Gazeta Wyborcza”, 24.04. 
Magdalena Ickiewicz-Sawicka

\title{
BOSNIAN MUSLIMS (BOSNIAKS) IN THE FACE OF CRIMINOLOGICAL AND RADICAL ISLAM IN THE BALKANS - THE CASE OF BOSNIA AND HERZEGOVINA
}

\begin{abstract}
(Summary)
The article entitled: Bosnian Muslims (Bosniaks) in the face of criminological and radical Islam in the Balkans - the case of Bosnia and Herzegovina consists of two main parts. The first one contains considerations on the national-ethnic identity of the Bosnian Muslims. In the second part of the article placed on the analysis of the radical (fundamentalist and radical) Islam in the Balkans with a special focus on their activities in the territory of Bosnia and Herzegovina. In this part of the text I included information on the number of groups and organizations promoting radical Islam as an ideology of the Wahhabis. Generally the article attempts to unravel this complex and multidimensional Bosnian identity and mentality, which on the one hand, presents the exoticism of the Orient, but on the other hand, has an unquestionable south pedigree, which has been seriously overvalued as a result of wars and dangerous radical, ultra-conservative Islam.
\end{abstract}

